\title{
Metallogenic characteristics and genesis of granite type uranium ore bodies in South China
}

\author{
Liu Zekun ${ }^{1,2, *}$ \\ ${ }^{1}$ Institute of Mineral Resource, Chinese Academy of Geological Science, Beijing 100037, China \\ ${ }^{2}$ China University of Geosciences, BeiJing 100083, China
}

\begin{abstract}
South China is the key producing area of granite-type uranium deposits in China. After decades of exploration, many important progress has been made in the study of metallogenic regularity of granite type uranium deposits in this area. On the basis of previous studies, this paper attempts to sort out the geological conditions and characteristics of diagenesis and mineralization of granite type uranium deposits in South China, and discuss their metallogenic models, so as to better summarize the metallogenic regularity and serve the prospecting and prediction.
\end{abstract}

\section{Introduction}

Uranium resource is not only an important strategic resource and energy mineral in China, but also a basic raw material for the development of China's nuclear industry [1]. Uranium resources in China are characterized by wide distribution, complex deposit types, small scale of single deposit, complex ore body shape and low and medium grade deposits. According to the host rocks, the main industrial uranium deposits in China can be classified into four types: granite type, volcanic rock type, sandstone type and carbonaceous siliceous mudstone type [2]. Granite type uranium deposits in South China are the earliest type of uranium deposits found in China. It has been more than 60 years since the discovery of the first granite type uranium deposit, the Xiwang uranium deposit, in the 1950s. After more than 60 years of exploration, granite type uranium deposits in South China are considered to be the most important type of uranium deposits in China.

Granite type uranium deposits are hydrothermal uranium deposits with close spatial and genetic relationships with granite bodies. They occur in or near the granite. Uranium bearing granite refers to the rock body in which uranium deposits closely related to rocks are found in or around the rock. China is the country with the most developed granite type uranium deposits, the most types and the most widely distributed. South China is the most concentrated area of granite type uranium deposits in China, accounting for $85.6 \%$ of the total granite type uranium deposits in China and $48.5 \%$ of the total proven uranium deposits in South China [3]. Therefore, the study of uranium mineralization characteristics of uranium bearing granites in South China is helpful to explore the genesis of granite type uranium deposits in South China and has important guiding significance for prospecting.

\section{Temporal and spatial distribution of granite type uranium deposits in South China}

In South China, multi-stage granites are widely developed and rich in tungsten, tin, niobium, tantalum, uranium and other metal minerals with close genetic relationship. The exposed area of granite in South China is $200000 \mathrm{~km}^{2}$, accounting for about $20 \%$ of the total area of the area. Uranium bearing granites occur mostly in paleo uplift areas, especially in Caledonian fold belts. Uranium rich granite bodies in South China are mainly distributed in southern Jiangxi and northern Guangdong (such as Wanyangshan-Zhuguangshan granite body, Guidong granite body, Longyuanba granite body, Dafuzu granite body, Aigao granite body, Taoshan granite body, etc.) (Fig.1), followed by Northern Guangxi (such as Miaoershan-Yuechengling granite body, Motianling granite body), and a small amount in central Jiangxi (such as Jintan granite body), in which Zhuguangshan pluton and Guidong pluton in the north of Guangdong Province produce the most uranium deposits, accounting for about $50 \%$ of all types of uranium deposits in South China, and occupy the majority of uranium resources in this region [4].

*Corresponding author: zzkk_5566@163.com 


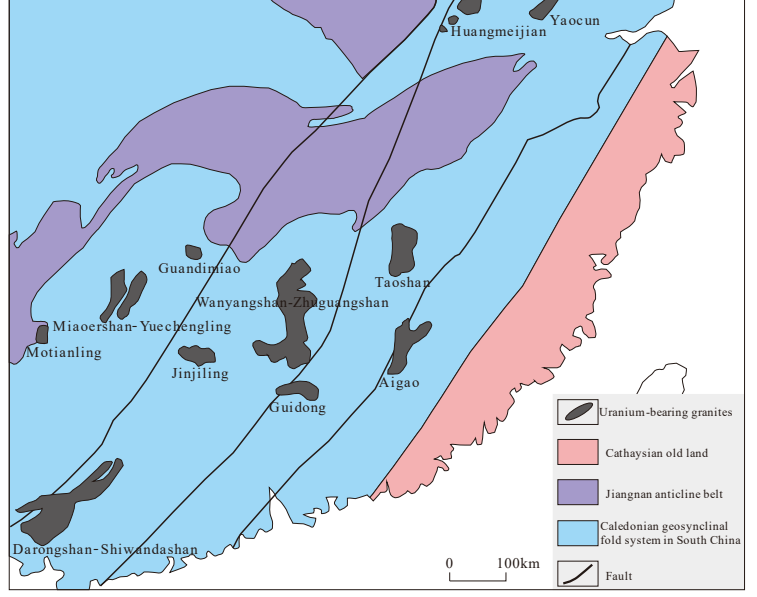

Fig.1 Map showing the distribution of the main uraniumbearing granites in South China (modified from Chen Zhenyu et al., 2014)

The uranium bearing granites in South China are generally multi-stage intrusions from Caledonian to Yanshanian, except for a few simple intrusions of old age (Jinning Motianling granites). After the emplacement of uranium bearing granites in south China, most of them were intruded by late magma and formed complex plutons. The emplacement age of granites directly related to uranium mineralization is mainly Indosinian, followed by early Yanshanian.

The mineralization time of granite type uranium deposit is obviously later than that of granite diagenesis, and the time difference between mineralization and diagenesis is 700 40Ma. The metallogenic epoch of granite type uranium deposits in South China is extensive and the time span is large. The time of uranium mineralization is generally late Yanshanian and Himalayan. The granite type uranium mineralization in South China has obvious regional simultaneity. The time of diagenesis and mineralization is discontinuous. There are six main metallogenic periods of granite type uranium deposits in South China, which are about 140, 120, 100, 90, 70 and $50 \mathrm{Ma}$ ago. In addition, a deposit often has multiple metallogenic ages, indicating that the mineralization has the characteristics of multi-stage and multi-stage [4].

\section{Metallogenic characteristics of granite type uranium deposits in South China}

\subsection{Petrological characteristics}

Uranium rich granites in South China are usually largescale multi-stage or contemporaneous multi-stage complex rocks. The lithology of uranium bearing rocks is mostly biotite granite or two-mica granite. The genesis types of uranium rich granite in South China are mostly Stype granites with over aluminous, and the number of uranium deposits produced in them accounts for $93 \%$ of the total number of granite type uranium deposits in South China; secondly, A-type granite, which accounts for about $7 \%$ of the total. The internal structure of the rock mass is relatively developed, and it is often cut and filled by late Yanshanian intermediate basic dyke, acid small rock mass and large quartz vein, or manifested as silicified fault zone, mylonitized zone, breccia zone, schistosity zone and so on. It is accompanied by extensive metasomatic alteration and hydrothermal alteration. Uranium mineralization is controlled by various structures, alteration zones and contact interfaces between different stages of rock mass. Uranium deposits occur either in the edge of the rock mass, or in the sedimentary - low metamorphic wall rock of the contact zone outside the rock mass, or in the contact zone of different stages of the rock mass.

\subsection{Mineralogical characteristics}

The main rock forming minerals of uranium rich granites in South China include potash feldspar, plagioclase, biotite, muscovite and quartz. Potash feldspar is the main mineral component of uranium bearing rock mass, and its content generally accounts for more than $1 / 3$ of the total minerals; Biotite is one of the main components of uranium bearing rock mass. As far as a compound rock mass is concerned, its content tends to decrease gradually from early to late ages. Biotite is an important carrier mineral of uranium in granite, which can release a large amount of active uranium in the process of later alteration and muscovitization, providing an important uranium source for mineralization. The mineralogical chemistry of biotite is often used to distinguish and study the petrogenesis and metallogenic potential. The content of quartz in uranium bearing rock is different, but for a multistage complex rock, its content increases gradually from early to late. The mineral assemblages are mainly pitchblende, quartz, fluorite, calcite, pyrite and hematite [5].

Uraninite is the most important uranium bearing mineral and uranium source mineral in granite. The higher the content of uraninite in granite, the greater the probability of becoming a uranium producing rock mass. Pitchblende is also an important primary ore-forming mineral in granite type hydrothermal uranium deposits, and even the only primary uranium mineral in some uranium deposits.

Most uranium producing granites are highly altered. Potassic alteration, albitization, illitization, hematization, chloritization, montmorillonization and kaolinification are common in granite type uranium deposits. Alkaline metasomatism (potassic feldsparization and albitization) is a process of uranium preconcentration. Uranium mineralization is generally related to late acid metasomatism. The main alteration includes hematization, silicification, chloritization and illitization. From the mineralization center to the outside, there are horizontal alteration zoning of silicification hematization strong illitization, strong chloritization weak illitization, weak chloritization montmorillonite (kaolinification) fresh granite. The vertical alteration zoning of granite type uranium deposits is not obvious. Some uranium deposits have the alteration characteristics of "acid above and alkali below".[6] The superimposed area of multi-stage structural alteration and the cross area of acid-base 
alteration are favorable metallogenic sites[7].

\subsection{Geochemical characteristics}

Uranium bearing granites in South China are usually rich in silicon $\left(\mathrm{SiO}_{2}\right.$ content is mostly $\left.70 \% \sim 75 \%\right)$ and alkali $\left(\mathrm{Na}_{2} \mathrm{O}+\mathrm{K}_{2} \mathrm{O}\right.$ content is usually more than $\left.7 \%\right)$. The content of $\mathrm{K}_{2} \mathrm{O}$ is greater than that of $\mathrm{Na}_{2} \mathrm{O}$. They belong to aluminum supersaturated series with low dark component content. The total REE content of uranium bearing plutons in South China is generally low, relatively enriched in LREE and negative Eu anomaly. Generally speaking, these uranium bearing bodies are rich in oreforming elements such as $\mathrm{W}, \mathrm{Sn}, \mathrm{REE}, \mathrm{Li}, \mathrm{Be}, \mathrm{Rb}, \mathrm{CS}$ and Ta [8].

\section{Formation mechanism of uranium - rich ore bodies}

Uranium mineralization is a dynamic process of uranium source-transportation-preservation-change. Granite type uranium deposits in South China are the products of tectonic evolution magmatism metallogenic fluid system evolution. The final enrichment of uranium deposits can be summarized as: strata preconcentration - rock preconcentration - structure alteration preconcentration vein filling industrial enrichment.

Sufficient uranium source is the basic premise for the formation of uranium rich ore bodies [9]. Therefore, the pluton intruding into the uranium rich area is a favorable condition for the formation of uranium bearing granite. The pre Sinian strata, especially the Neoarchean strata, that is, the early crust with high maturity formed in Paleoproterozoic, are the original source of uranium. The rock assemblage is dominated by shallow sea sub deep sea terrigenous clastic rock formation, intercalated with intermediate acid, basic volcanic formation, carbonate formation, siliceous rock formation, etc. Through the early Paleozoic tectonics - The uranium rich granite body was formed by remelting of uranium source bed during magmatism; The uranium that forms uranium deposits mainly comes from uranium enriched granite activated by uranium, but part of uranium may also come from uranium extracted from deep crust and upper strata by mantle fluid and uranium that tends to enter fluid during crystallization of acid magma melt in late Yanshanian.

Indosinian - the early Yanshanian period, under the residual action of mantle fluid in mantle plume, the uranium in uranium source layer entered into the hydrothermal solution and promoted the migration and enrichment of uranium. Granite type uranium mineralization in South China is closely related to late Yanshanian post orogenic extensional structures. In time, uranium mineralization is consistent with the extensional tectonic activity in the area. Spatially, uranium deposits mainly occur in the secondary structural belt of regional extensional structure. The superimposition of multi-stage hydrothermal alteration, strong rock fragmentation, alteration and metamorphism provide more uranium sources for the formation of uranium rich ore bodies, and promote multiple migration and enrichment of uranium
[10].

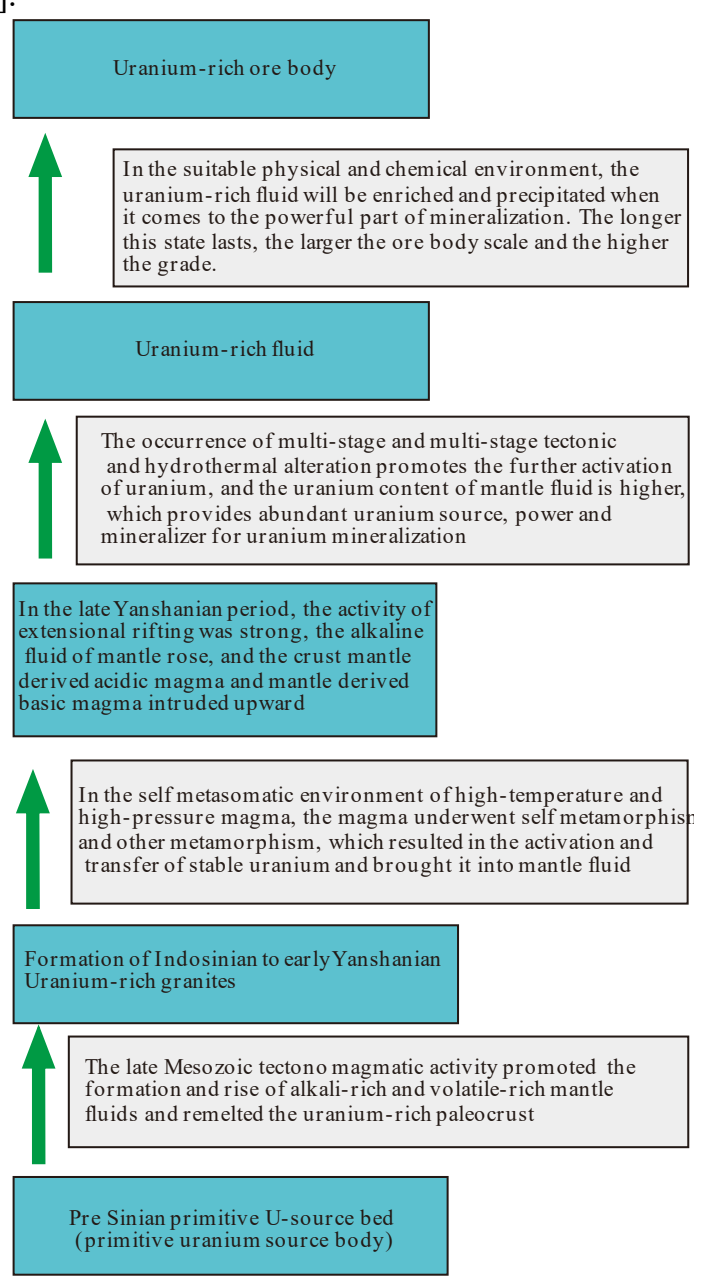

Fig.2 Metallogenic model of granite type uranium rich orebodies in South China (modified from Xu Lili et al., 2017)

\section{Conclusions}

(1) Uranium-producing granitoids in South China are generally complex granitoids from Caledonian to Yanshanian. Uranium-producing granitoids are calcalkaline rocks with high silicon, high potassium and peraluminous quality, and have the characteristics of intracontinental S-type granitoids. The source area of the granitoids is related to extremely mature continental crust.

(2) The formation of uranium-rich ore body is the result of the superposition of many factors, such as uranium source, structure, magmatism, multiple activation and migration of uranium, favorable physical and chemical conditions, precipitation enrichment and mineralization in favorable tectonic positions, which can lead to the formation of uranium ore body.

(3) The pre Sinian strata are one of the important source beds of uranium in South China. The melting of Indosinian and Yanshanian magmatism made the uranium in continental crust pre enriched in granite, which provided the material basis for the hydrothermal uranium mineralization after diagenesis. The regional uranium source bed is the basic material source of granite type uranium deposits in South China. 


\section{References}

1. Cai Y.Q., Zhang J.D., Li Z.Y., Guo Q.Y., Song J.Y., Fan H.H., Liu W.S., Qi F.C., Zhang M.L. (2015) Outline of Uranium Resources Characteristics and Metallogenetic Regularity in China. Acta Geologica Sinica, 89(06): 1051-1069.

2. Huang J.B., Huang S.J. (2005) Regional metallogenic characteristics of China's uranium resources. Uranium Geology, (03): 129-138.

3. Shao F., Xu J.J., Shao S., Yao P.F., Liu K., Wu W.T., Zhang Y. (2014) Geological characteristics and mineralization of the granite-type uranium deposits in south China. Resources Survey and Environment, 35(03): 211-217.

4. Chen Z.Y., Huang G.L., Zhu B., Chen ZH., Huang F., Zhao Z., Tian Z.J. (2014) The Characteristics and Metallogenic Specialization of Granite-hosted Uranium Deposits in the Nanling Region., Geotectonica et Metallogenia , 38(02): 264-275.

5. Hu R.Z., Luo J.C., Chen Y.W., Pan L.C. (2019) Several progresses in the study of uranium deposits in South China. Acta Petrologica Sinica, 35(9): 26252636.

6. Zhao R.Y., Wang D.H., Chen Y.C., Leng C.B., Qin J.H., Zhao C.H. (2020) Geological haracteristics, metallogeny and geospatial mineralization model of uranium in the Nanling metallogenic belt. Acta Geological Sinica, 94(01): 149-160.

7. Xu H., Cai Y.Q., Zhang C., Guo C.Y., Liu J.L. (2018) Metallogenetic Geological Feature and the Prediction Model for Prospecting Granite Type Uranium Deposit in South China. Uranium Geology, 34(02): 65-72+89.

8. Shao F., Xu J.J., Mao Y.F., He X.M., Gao M.Q. (2013) Study on Mineral Discharge Mechanism of Granite Type Uranium Deposits in South China Uranium Metallogenic Province. Uranium Geology, 29(03): 146-151+171.

9. XU L.L., LI Z.S., TAN Z.Z. (2017)Analysis of the metallogenic conditions and model of the granite type uranium-rich orebody in southern China. Mineral Exploration, 8(02):239-247.

10. Zhang Y.T., Pei R.F., Zhang X.P., Ni X.Y., Wang Q.B., Tang G.P., Chen Y.F. (2012) Metallogenic Condition of Granite Type Uranium Deposit and its Potential in Southern Jiangxi Province. Uranium Geology, 28(01): 28-34.

11. Ling H.F. (2011) Origin of Hydrothermal Fluids of Granite-type Uranium Deposits: Constraints from Redox conditions. Geological Review, 57(02): 193206.

12. Wu J.H., Guo G.L., Guo J.L., Zhang Q., Wu R.G., Yu D.G. (2017) Spatial-temporal distribution of Mesozoic igneous rock and their relationship with hydrothermal uranium deposits in eastern China. Acta Petrologica Sinica, 33(5): 1591-1

13. Xu J.J., Shao F. (2015) Review of study on transportation and deposition mechanisms of ore- forming element for granite type uranium deposit in South China. World uranium resources, 32(03): 132138 . 